\title{
Influence of Self-esteem on Academic Performance Among Secondary School Students
}

\author{
Dr (Mrs.) Funmilola Bosede Alokan, Dr (Mrs) Joyce Olufunke Ogunsanmi, \\ Dr. (Mrs.) Veronica Ibitola Makinde, Mrs. Bosede Oluwayemisi Fashina \\ Department of Guidance and Counselling, Faculty of Education, Ekiti State University, Ado - Ekiti, Ekiti State, \\ Nigeria
}

\begin{abstract}
This study investigated the difference between the academic performance of students with high selfesteem and students with low self-esteem. A descriptive research design of survey type was adopted for the study. The population for this study comprised all public secondary school students in Ondo state. The sample consisted of 240 students from six randomly selected schools. A questionnaire tagged 'Academic Performance Questionnaire' was used to collect data. Expert judgements were used to ensure face and content validity. Testretest method was used to determine the reliability and a reliability coefficient of 0.72 was obtained. Data collected were analysed by using $t$-test. The result revealed that there is a significant difference in the academic performance of students with high self-esteem and students with low self-esteem. It can be concluded from the result that students with high self-esteem perform better in school work than students with low self-esteem. It was recommended that parents should help their children to see themselves in positive light. They should also desist from belittling their children and doing things that can deflate their self-esteem.
\end{abstract}

\section{Introduction}

The construct of self-esteem dates back to William James, in the late 19th century. In his work 'Principles of Psychology, James (1890) studied the splitting of our "global self' into "knower self" and "known self". According to him, from the self which we all are more or less aware of, self-esteem is born.

In the 20th century, the initial influence of behaviourism minimized introspective study of mental processes, emotions and feelings, which was replaced by objective study through experiments on behaviours observed in relation with environment. As a result of this, scientific study of self-esteem was overlooked (Bonet, 1997). Bonet went further to say that in the mid-20th century, phenomenology and humanistic psychotherapy made self-esteem gain prominence again, and it took a central role in personal self-actualization and in the treatment of psychic disorders. Psychologists started to consider personal satisfaction and psychotherapy, and new elements were introduced, which helped to understand the reasons why people tend to feel less worthy, discouraged and unable to understand challenges by themselves.

Carl Rogers (1902 - 1987), a great exponent of humanistic psychology, exposed his theory about unconditional acceptance and self-acceptance as the best way to improve self-esteem. According to Wikipedia (2013), self esteem is a collection of an individual's attitudes toward himself. The human being perceives himself at a sensory level; thinks about himself and about his behaviour, and evaluates both his behaviour and himself. Consequently, humans feel emotions related to themselves. These emotions prompt behavioural tendencies aimed at oneself, at one's behaviour, and at the features of one's body and character. These tendencies effect the attitudes which, globally, we call self-esteem.

Judge, Locke and Durham (1997) stated that the core self-evaluations approach includes self-esteem as one of four dimensions that comprise one's fundamental appraisal of oneself, along with locus of control, neuroticism and self-efficacy. They went further to say that the concept of core self-evaluations has since proven to have the ability to predict several work outcomes, specifically job performance. Self-esteem may, in fact, be one of the most essential core self-evaluation dimensions because it is the overall value one feels about oneself as a person (Judge, Locke, Durham and Kluger, 1998).

In United States, the idea of the importance of self-esteem, especially in education, has gained endorsement from some government and non-government groups, such that one can speak of a self-esteem movement (Nolan, 1998). Self-esteem is a disposition that a person has which represents his judgment of his own worthiness (Olsen, Breckler and Wiggins, 2008). Branden (1969) stated that self-esteem is the experience of being competent to cope with the basic challenges of life. he also said that self-esteem is the sum of selfconfidence (a feeling of personal capacity) and self-respect (a feeling of personal worth).

Some writers use the terms, self-concept and self-esteem interchangeably. They are closely related but they do have distinct meanings. The formation of self-concept is a cognitive act that requires self-assessment and is differentiated across a range of activities; while self-esteem is an affective act and encompasses the value or worth we attach to our self-assessments. Self-esteem is considered being less malleable than self-concept. It 
is about the ways that an individual feels about his strengths and weaknesses. High self-esteem comes from our competence in the things we value, while low self esteem is the outcome of negative judgements when individuals focus on their weaknesses.

As self-aware and self-reflective creatures, many people intuitively recognize the importance of selfesteem. not surprisingly, a great deal of psychological theorizing has focused on the motivation to protect and, if possible, enhance self-esteem. research is showing that even psychodynamic defense mechanisms which Freud originally understood as ways of keeping threatening sexual and aggressive impulses at bay, serve as strategies to bolster self-esteem (Baumelster, Dale and Sommer, 1998).

The word 'floccinaucinihilipilification' which is allegedly the longest word in the Oxford English Dictionary is defined as "the action or habit of estimating as worthless". The definition of low self-esteem involves making a disparaging or low-worth judgement about the self.

Self-esteem has become a household word. Teachers, parents, therapists and others have focused efforts on boosting self esteem, on the assumption that high self-esteem will cause many positive outcomes and benefits - especially good academic performance in schools. Many studies have found that self-esteem is positively correlated with academic performance. Hansford and Hattie (1982) did meta-analysis of 128 studies involving more than 200,000 participants. These studies explored a variety of measures of self-esteem and a variety of objective performance measures, most of which were achievement tests. The correlations reported varied widely, from -.77 to +.96 , and averaged between +.21 and +.26 . Hansford and Hattie (1982) concluded that overall, there is a significant positive relationship between self-esteem and academic performance, with self-esteem accounting for between 4 and $7 \%$ of the variance in academic performance.

An early study by Bachman and O'malley (1977) used data from a nationwide longitudinal study that tracked more than 1,600 young men from 1966, when they were in 10th grade, up through 1974. All participants in this study completed a modified version of the Rosenberg (1965) self-esteem scale at several points during this period. Bachman and O'malley found that self-esteem correlated with school performance. another study was conducted by Maruyana, Rubin and Kingsbury (1981). This study focused on a much younger age. Maruyana et al followed a final sample of more than 700 students from age 4 to age 5. Achievement was measured using academic achievement tests, including the Stanford achievement test and later, the wide range achievement test, which emphasizes spelling, vocabulary and arithmetic. They also found that self esteem and academic achievement are correlated. on their own part, using standard achievement tests, Davies and Brember (1999) found significant positive relationship between self-esteem and academic performance in a large sample of 3001 British respondents. These results give foothold to the credence that self-esteem is gaining.

\section{Statement of the Problem}

The self-esteem movement has been especially influential in American schools, and part of the reason for this is the assumption that raising self-esteem will lead to improvements in children's academic performance.

There has been growing concern about the poor academic performance of students in our schools in Nigeria. All possible avenues for solution are being explored. The researchers wanted to ascertain whether high self-esteem is in fact a cause of positive or negative outcomes in Nigeria. To this end, the following hypothesis was generated.

\section{Hypothesis}

There is no significant difference between academic performance of students with high self-esteem and students with low self-esteem.

\section{Methodology}

The researchers used descriptive research design of survey type. The plan of study involved the use of questionnaire to collect data in order to test the hypothesis generated in the study. The target population for this study was made up of public secondary school students in Ondo state Nigeria who were in Senior Secondary School one. This class of students was chosen because the students faced a uniform examination throughout the whole state at end of previous session, that is at the end of their Junior Secondary School three. Their results in this examination were used to measure academic performance.

Stratified random sampling was used to draw out the sample. Three schools were chosen randomly from urban areas and three schools were also randomly chosen from rural areas. In each school, 40 students of both sexes were selected, making a total of 240 students.

A self-designed questionnaire called 'Academic Performance Questionnaire'(APQ) was used for the study. Part A was designed to collect information on background characteristics of respondents. Part B consisted 27 items on environmental and psychological factors including self-esteem. 
The methods used in validating the instrument were face and content validity. Experts judgements were used to determine both. A reliability test was also carried out on 20 Senior Secondary School one students who were not part of the sample. The scores obtained from two administrations of the questionnaire at two weeks interval were correlated by using Pearson Product Moment Correlation. A reliability coefficient of 0.72 was obtained. The instrument was found to be suitable for data collection.

Copies of the questionnaire were distributed by the researchers and school counsellors to a sample of 240 students in six schools. Researchers' presence during administration enhanced better understanding of the items in the instrument. Copies of the questionnaire were collected back immediately after completion by the researchers.

The results of the external and uniform Junior Secondary School Certificate Examination were collected from the principals of the schools. These were used to measure the academic performance of the students.

The data generated were analysed using t-test. The hypothesis was tested at 0.05 level of significance.

\section{Testing of Hypothesis}

There is no significant difference between academic performance of students with high self - esteem and students with low self - esteem.

In testing this hypothesis, the mean total score and standard error obtained on academic performance of students with high self - esteem and students with low self-esteem were subjected to t-test analysis at 0.05 level of significance.

The t-test showing the academic performance of students with high and low self-esteem.

\begin{tabular}{|l|l|l|l|l|l|l|}
\hline Group & $\mathrm{N}$ & Mean & sd & df & tcal & ttable \\
\cline { 1 - 5 } High self-esteem & 79 & 2.2321 & 1.40927 & & & \multirow{2}{*}{1.960} \\
\hline Low self-esteem & 161 & 2.7236 & 1.39183 & 238 & 2.560 & 1.960 \\
\hline
\end{tabular}

$\mathrm{p}<0.05$

The table shows that the mean score of respondents with high self-esteem is 2.2321 with standard deviation of 1.40927 while the mean total score of respondents with low self-esteem is 2.7236 with standard deviation of 1.39183 . The t-calculated is 2.560 while the table value is 1.960 . The t-calculated is greater than ttable. The null hypothesis is rejected. This implies that there is significant difference between academic performance of students with high self-esteem and students with low self-esteem.

There are plausible reasons for thinking that high self-esteem will lead to good schoolwork, while low self-esteem will lead to poor academic performance. People with high self-esteem may set higher aspirations than people with low self-esteem. They may be more willing to persist in the face of initial failure and less likely to succumb to paralyzing feelings of incompetence and self doubt. This result is in line with the findings of Bachman and O'malley (1977), Maruyana, Rubin and Kingsbury (1981), Hansford and Hattie (1982) and Davies and Brember (1999) which stated that self-esteem is positively correlated with academic performance.

Learning, by definition, involves acquiring information and skills that one does not initially have, and high esteem may help prevent the recognition of one's initial incapability from producing a sense that the cause is hopeless. high self-esteem may foster the confidence to tackle difficult problems and enable people to derive satisfaction from progress and success.

\section{Conclusion and Recommendation}

Evidence from the study has led the researchers to conclude that students with high self-esteem perform better in school work than students with low self-esteem.

In view of this, it is recommended that parents should build up the self-esteem of their children. They should help their children to see themselves in positive light. Parents should desist from belittling their children and doing things that can deflate their self-esteem.

\section{References}

[1]. Bachman J.G. and O'malley P.M. (1977). Self esteem in young men: Analysis of the impact on educational and occupational attainment. Journal of Personality and Social Psychology, 33:365 - 380 .

[2]. Baumeister R.F.; Dale K. and Sommer K.L. (1998). Freudian defense mechanisms and empirical findings in modern social psychology. Journal of Personality, 66:1081 $\quad-1124$.

[3]. Bonet, jose - vicente (1997). Se amigo de ti mismo: Manual de autoestima. ed. sal terrae. maliano (cantabria, espana).

[4]. Branden, N. (1969). The psychology of self-esteem. New York: Bantam.

[5]. Davies, Jand Brember, i. (1999). Reading and mathematics and self-esteem: an eight-year cross-sectional study. Moral Studies, 25:145 -147 .

[6]. Hansford, B.C and Hattie, J.aA (1982). The relationship between achievement/ performance measures. Review of Educational Research, 62:123-142.

[7]. James William (1890). Principles of psychology. London: Macmillan. 
[8]. Judge, T.A.; Locke, E.A. and Durham, C.C. (1997). The dispositional causes of job satisfaction: A core evaluations approach. Research in Organizational Behaviour, 19:151 - 188.

[9]. Judge, T.A.; Locke, E.A. and Durham, C.C. and Kluger, A.N. (1998). Dispositional effects on job and life satisfaction: The role of core evaluations. Journal of Applied Psychology, 83(1): 17 - 34

[10]. Maruyana, G.; Rubin, R.A and Kingsbury, K.G. (1981). Self - esteem and educational achievement: Independent constructs. Journal of Personality and Social Psychology, 40:962 - 975.

[11]. Nolan, J.L. (1998). The therapeutic state: Justifying government at century's end. http://books.google.com.

[12]. Olsen, J.M.; Breckler, S.J. and Wiggins, E.C. (2008). Social psychology alive. Canada: Nelson.

[13]. Rosenberg, M. (1965). Society and the adolescent self-image. Princeton, NJ: Princeton University Press.

[14]. Wikipedia (2013). Self-esteem. http://en.wikipedia.org 